\title{
CXCL16 wt Allele
}

National Cancer Institute

\section{Source}

National Cancer Institute. CXCL16 wt Allele. NCI Thesaurus. Code C104144.

Human CXCL16 wild-type allele is located in the vicinity of $17 \mathrm{p} 13$ and is approximately $6 \mathrm{~kb}$ in length. This allele, which encodes C-X-C motif chemokine 16 protein, may play a role in lymphocyte chemotaxis and scavenger receptor for oxidized low density lipoprotein. 